\title{
MICROBIAL COMMUNITY CHARACTERISTICS OF A HIGH SOLID CONTENT ANAEROBIC DIGESTER OF MUNICIPAL SOLID WASTE
}

\author{
Kou, W. - Zhang, D. - ShaO, L. - Dong, X. - WANG, X. - MA, M. - LIU, P. - YU, M. \\ Liaoning Institute of Energy Resources \\ Yingkou, 115003, China \\ (phone: +86-417-4845773; fax: +86-417-4845773) \\ *Corresponding author \\ e-mail: yu-meiling@163.com \\ (phone: +86-417-4845771; fax: +86-417-4845773) \\ (Received $3^{\text {rd }}$ Aug 2016; accepted $12^{\text {th }}$ Oct 2016)
}

\begin{abstract}
The composition of municipal solid waste (MSW) was examined, including water content, cellulose content, organic ingredients, etc. Throughout the anaerobic digestion of the organic waste, the characteristics of anaerobic acidifying bacteria, ammonifying bacteria, cellulose-degrading bacteria and methane bacteria were analyzed with respect to time and spatial distribution. The function of the microbial community and the relationship between the metabolites were analyzed as well. The results showed that in the initial stage of anaerobic fermentation of municipal waste, large amounts of oxygen in the reactor enabled aerobic and facultative anaerobic bacteria to proliferate and transform most of the raw material into organic matter. With the formation of the anaerobic, nutrient-rich environment the number of anaerobic bacteria began to rise. Anaerobic acidifying bacteria reached a maximum number sooner and remained higher than ammonifying bacteria. Methane bacteria did not proliferate during the startup phase; the peak concentration of $3.36 \times 10^{9} / \mathrm{mL}$ occurred at the 25 th day, then remained stable. The anaerobic cellulose-decomposing bacteria grew slowly. Within the reactor, the numbers of anaerobic acidifying bacteria, anaerobic ammonifying bacteria and methane bacteria were higher in the middle and bottom positions; the anaerobic cellulose-decomposing bacteria proliferated at the bottom. In addition, the change trends of volatile fatty acids and ammonia nitrogen concentration were consistent with the spatial distribution of the bacteria. The VFA composition of biogas slurry was primarily butyric acid, indicating that butyric acid fermentation was the dominant process.
\end{abstract}

Keywords: anaerobic acidifying bacteria, ammonifying bacteria, cellulose-degrading bacteria, methane bacteria, time and spatial distribution, relationship of the metabolites

\section{Introduction}

The quantity of municipal solid waste produced in China has increased by $8-10 \%$ per year over the past several decades (Shi et al., 2008). Of the 170.8 million tons created in 2012, $61.5 \%$ of the waste went to landfills, $21.0 \%$ was incinerated, and less than $2.3 \%$ was treated through anaerobic fermentation (China, 2012). Traditional landfills can cause problems such as the generation of heavily polluted leachates (Renou et al., 2008; Igoni et al., 2005) and the emission of volatile organic compounds and odors (Gonzáleza et al., 2013), which present a significant threat to public health and the environment. With food waste making up the largest fraction (50\%) of MSW in China, and with moisture levels around 50\% (Cheng and $\mathrm{Hu}, 2010$; Hartmann and Ahring, 2006), the anaerobic fermentation process is a feasible way to reduce the 
consumption of fossil fuel. If the organic component of MSW is converted into energy through anaerobic digestion, it will reduce the adverse impact on the environment and contribute to the production of new energy. Anaerobic digestion is a process by which complex organic materials are first hydrolyzed and fermented by acidifying bacteria into volatile fatty acids (VFA) (Wan et al., 2013; Igoni, 2006). The VFA are then consumed by methanogenic bacteria and converted into methane gas. However, not all organic components of MSW can be digested easily (Macias-Corral et al., 2008; Nopharatana et al, 2007).

A number of anaerobic processes such as wet or dry fermentation have been adopted and developed for the treatment of MSW (Tyagi et al., 2014; De Baere and Mattheeuws, 2010). Because the traditional wet fermentation process requires the addition of water to the fermentation material and produces residual waste byproducts, building a wet fermentation biogas plant would require more equipment and investment than other types (Motte et al., 2013; Ghosh et al, 2000). Anaerobic fermentation of high solid content waste is becoming a research focus. Several factors affect the dry fermentation process for biogas production, such as $\mathrm{pH}$, ammonia inhibition, and the microbial community (Yin et al., 2014). Controlling the microbial community in particular could affect the efficiency of biogas production (El-Mashad et al., 2008; Eikmeyer et al., 2013; Kovács et al., 2013). Previous research has suggested that adjusting parameters such as substrate concentration and initial solid waste composition could improve the environment for anaerobic digestion (Fernández et al., 2008), and that mixing different types of organic waste may also improve biogas production (Li et al., 2010). However, few studies to date have directly analyzed the microbial community in dry anaerobic fermentation to improve the digestion process.

In this study, microbial community composition was investigated during dry anaerobic fermentation in a vertical reactor designed by our research group. The presence of volatile fatty acid (VFA), ammonia concentration and biogas production were measured over time at different locations within the reactor. Observation of the changes in the microbial community leads to understanding of the relationship between the microbial community and organic conversion.

\section{Material and methods}

\section{Feedstock selection}

Raw materials were collected from a landfill in Yingkou, China. Nonbiodegradable substances such as metal, waste residue, glass and fabric were sorted out of the municipal garbage. The physical and chemical properties of fermentation materials were analyzed, as shown in Table 1. The inoculum was a biogas slurry using pig manure as fermentation feedstock $(8.64 \% \mathrm{TS}, 3.52 \%$ VS). 
Table 1. Physical and chemical properties

\begin{tabular}{c|c|c|c|c}
\hline Month & $\mathbf{1 ~ 3}$ & $\mathbf{4 \sim 6}$ & $\mathbf{7 \sim 9}$ & $\mathbf{1 0 \sim 1 2}$ \\
\hline TS \% & 48.4 & 36.4 & 31.9 & 36.8 \\
VS \% & 42.88 & 30.35 & 27.68 & 31.39 \\
TOC \% & 25.1 & 18.9 & 24.2 & 24.5 \\
TN \% & 2.08 & 1.84 & 1.95 & 1.98 \\
pH & 6.72 & 5.91 & 5.90 & 6.12 \\
Protein \% & 12.49 & 11.62 & 12.11 & 11.87 \\
Fat \% & 8.81 & 5.55 & 7.31 & 7.24 \\
Cellulose \% & 9.21 & 12.55 & 13.80 & 11.61 \\
Hemicellulose \% & 2.95 & 3.23 & 3.45 & 3.24 \\
Lignin \% & 1.78 & 2.24 & 2.25 & 1.87 \\
Reducing & & & & \\
sugar \% & 2.34 & 2.83 & 3.32 & 1.95 \\
Lower heat & 9412 & 4734 & 4038 & 5541 \\
value (kJ/kg) & & & & \\
\hline
\end{tabular}

\section{Fermentation design}

The test device was a batch reactor for mesothermal $\left(37^{\circ} \mathrm{C}\right)$ anaerobic fermentation, as shown in Figure 1. The design incorporated six sampling positions: the top center, the top edge, the center, the middle edge, the bottom center and the bottom edge. The distance from the center to the edge was $15 \mathrm{~cm}$, the distance from the bottom sampling port to the tank bottom was $8 \mathrm{~cm}$, and the distance from the center to the top or bottom was $17 \mathrm{~cm}$. The device featured an external water bath circulation heating system The effective volume was $30 \mathrm{~L}$. The fermentation experiment used municipal solid waste that had been in the landfill for 4 to 6 months. Of the $18 \mathrm{~kg}$ of material added to the fermentation tank, the inoculum accounted for $30 \%$. The $\mathrm{pH}$ value was adjusted to 7.0. The gas produced by anaerobic fermentation in the reactor was recorded daily. Quanitities of ammonia nitrogen, acetic acid and propionic acid, as well as other parameters, were measured at each sampling port to assess the microbial community at different stages of fermentation. Each test was repeated three times and the results were averaged.

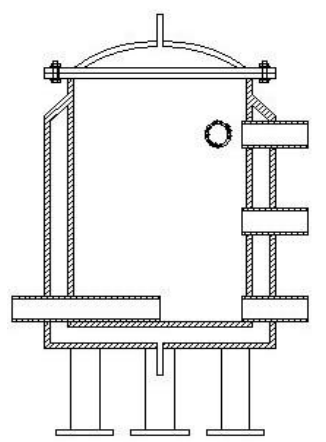

Figure 1. Anaerobic fermentation test device 


\section{Analytical method}

\section{Physicochemical property}

Gas production, methane content, ammonia nitrogen concentration, and volatile fatty acids were each analyzed according to the conventional index method (APHA, 1995).

\section{Microbial quantity determination}

The most probable number (MPN) method was followed to estimate a scope, or range, within a confidence interval, of the actual number of colonies based on the sample collected from the reactor. The MPN method was used for the following organisms:

Acidifying bacteria: MPN, training 2 days at $37^{\circ} \mathrm{C}$, a bromocresol purple indicator turning yellow showed a positive result.

Ammonifying bacteria: MPN, training 7 days at $28^{\circ} \mathrm{C}$, Nessler's reagent was added to the culture medium; generation of a precipitate indicated a positive result.

Cellulose-decomposing bacteria: MPN, training 30 days at $37^{\circ} \mathrm{C}$, when the filter paper in the medium produced gray translucent or yellow spots, the test result was positive.

Methane bacteria: MPN, the medium was prepared according to the Hungate technique, training 7 days at $37^{\circ} \mathrm{C}$, The presence of methane was detected by gas chromatography, then the MPN tables were used to determine the quantity of methane bacteria.

\section{Experimental reagents and culture medium}

Acidifying bacteria culture medium: The medium was composed of dipotassium phosphate $(0.4 \mathrm{~g})$, ammonium chloride $(1.0 \mathrm{~g})$, yeast cream $(1.0 \mathrm{~g})$, magnesium chloride $(1.0 \mathrm{~g})$, glucose $(8.0 \mathrm{~g})$, sodium chloride $(1.0 \mathrm{~g}), 1 \%$ bromocresol purple indicator $(5.0$ $\mathrm{mL})$, and water $(1,000 \mathrm{~mL})$, with a $\mathrm{pH}$ value of 7.0-7.2.

Ammonifying bacteria culture medium: The medium contained peptone $(5.0 \mathrm{~g})$, dipotassium phosphate $(0.5 \mathrm{~g})$, monopotassium phosphate $(0.5 \mathrm{~g})$, magnesium sulfate $(0.5 \mathrm{~g})$, and water $(1000 \mathrm{~mL})$, with a $\mathrm{pH}$ value of 7.0-7.2.

Cellulose-decomposing bacteria medium: The medium was composed of sodium hydrogen phosphate ammonia $(2.0 \mathrm{~g})$, monopotassium phosphate $(1.0 \mathrm{~g})$, peptone $(1.0 \mathrm{~g})$, magnesium sulfate $(0.5 \mathrm{~g})$, calcium carbonate $(5.0 \mathrm{~g})$, and calcium chloride $(3.0 \mathrm{~g})$. Inserted the $1 \times 10 \mathrm{~cm}$ filter into per tube.

Methane bacteria culture medium: The medium contained methyl alcohol $(3.5 \mathrm{~g})$, acetic acid $(3.5 \mathrm{~g})$, sodium acetate $(5 \mathrm{~g})$, ammonium chloride $(1 \mathrm{~g})$, monopotassium phosphate $(0.4 \mathrm{~g})$, magnesium chloride $(0.1 \mathrm{~g})$, dipotassium phosphate $(0.4 \mathrm{~g})$, yeast extract powder $(2 \mathrm{~g})$, and water $(1,000 \mathrm{~mL})$. For every $5.0 \mathrm{~mL}$ of medium, $1.0 \mathrm{~mL}$ of the sterile mixture solution of $5 \% \mathrm{NaHCO}_{3}$ and $1 \% \mathrm{Na}_{2} \mathrm{~S}$ was added. After sterilization at $121^{\circ} \mathrm{C}$, for every $5.0 \mathrm{~mL}$ of medium, $0.1 \mathrm{~mL}$ of sterile penicillin solution was added.

The anaerobic culture medium contained the same components as the aerobic and facultative anaerobic culture medium with the following additions: redox indicator $(0.1 \%)$, resazurin $(2 \mathrm{~mL})$ and reducing agent L-cysteine $(0.5 \mathrm{~g})$. 
Nessler's reagent: To prepare this solution, potassium iodide $(35.0 \mathrm{~g})$ and mercuric chloride $(1.3 \mathrm{~g})$ were dissolved in $70 \mathrm{~mL}$ distilled water and added to $4 \mathrm{~mol} / \mathrm{L}$ potassium hydroxide solution $(30 \mathrm{~mL})$, filtered when necessary, and stored in an airtight jar.

\section{Results and discussion}

\section{Biogas production and methane}

The process of dry anaerobic fermentation of MSW can be divided into a start-up period (1-15 d), rich phase (16-28 d), and continued gas phase (29-40 d). As Figure 2 shows, in the 3-4 days after feeding there was a small peak in gas production during the start-up period, however, the $\mathrm{CH}_{4}$ content was only $8.1 \%$. Following this small peak, the gas production decreased rapidly, while $\mathrm{CH}_{4}$ content increased gradually. By the 21 st day after feeding, $\mathrm{CH}_{4}$ content had reached $58.63 \%$. The amount of gas production reached its maximum value of $26.8 \mathrm{~L}$ on the 25 th day; the maximum methane content was $75.41 \%$ on the 27 th day. As the fermentation progressed, a large amount of organic matter was consumed within the fermentation substrate. At the same time, the physicochemical properties of the fermented liquid changed accordingly, and some harmful substances accumulated in the fermentation system. Microbial activity began to decrease after 27 days, as evidenced by the gradual decline in gas production.
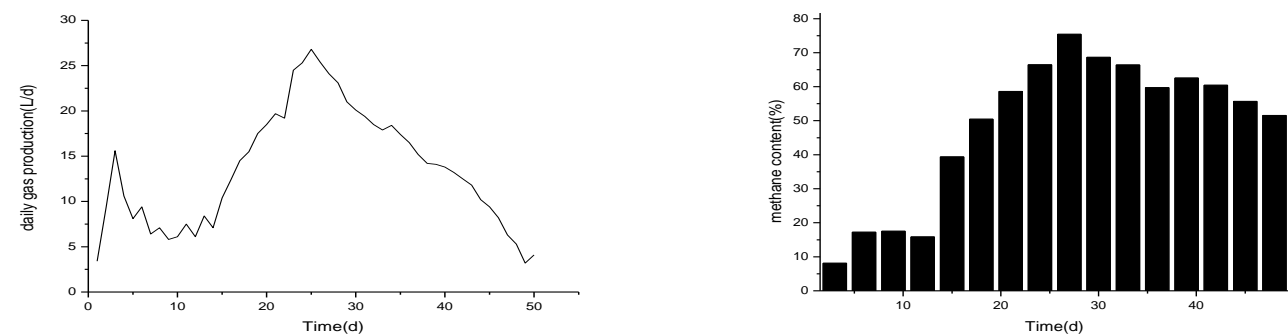

Figure 2. Trend of daily gas production and methane content

\section{Temporal and spatial distribution of microbial communities}

Aerobic and facultative anaerobic acidifying bacteria

As shown in Figure 3, y-axis representatived the logarithm bacteria number. The number of aerobic and facultative anaerobic acidifying bacteria rose rapidly to its peak value of $2.86 \times 10^{9} / \mathrm{mL}$, then decreased rapidly and maintained a stable trend within the range of $10^{6}-10^{8} / \mathrm{mL}$. In terms of tank position, the fastest growth distribution of aerobic and facultative anaerobic acidifying bacteria was observed in the top center position, followed by the top edge $\left(1.1 \times 10^{9} / \mathrm{mL}\right)$, the middle edge $\left(1.32 \times 10^{8} / \mathrm{mL}\right)$, the center $\left(7.02 \times 10^{7} / \mathrm{mL}\right)$, the bottom edge $\left(1.21 \times 10^{7} / \mathrm{mL}\right)$ and the bottom center $\left(6.11 \times 10^{6} / \mathrm{mL}\right)$, in that order. At the top center and top edge positions, these bacteria proliferated rapidly to the maximum quantity, but then fell sharply back to the initial value. The amplitude of the rise and fall at the two middle locations and the two bottom locations was not significant, 
indicating slow proliferation. At each level (top, middle, and bottom), there was no significant difference between the center and edge measurements.

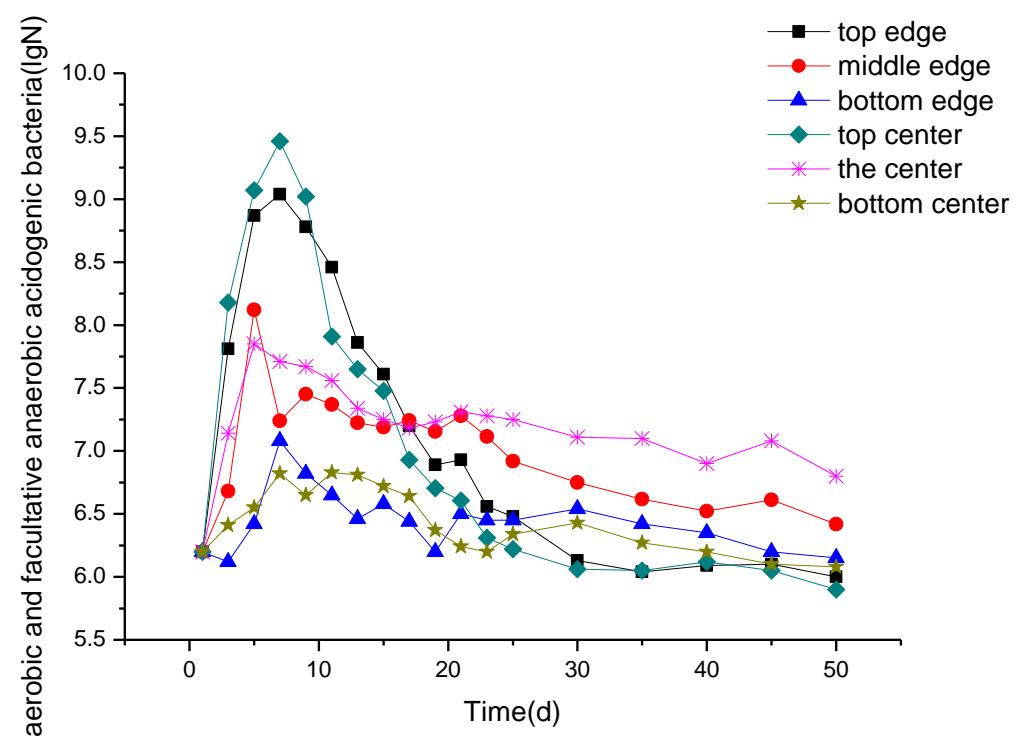

Figure 3. Space and time differences of aerobic and facultative anaerobic acidifying bacteria

In the top position, residual air provided the proliferation conditions for aerobic bacteria to produce acid. The conditions of the middle and bottom were relatively stable anaerobic environments. Therefore, acidifying bacteria proliferation was lower and mostly consisted of facultative anaerobes. Higher numbers at the middle positions compared to the bottom indicate that the anaerobic environment and nutrition conditions were more stable in the middle relative to the bottom.

\section{Aerobic and facultative anaerobic ammonifying bacteria}

As shown in Figure 4, the multiplication rate of aerobic and facultative anaerobic ammonifying bacteria was lower and reached its peak later than that of aerobic and facultative anaerobic acidifying bacteria. The maximum concentration of $2.11 \times 10^{8} / \mathrm{mL}$ was observed on the 15th day at the center location. Maximum values measured at the other positions are as follows: middle edge, $1.24 \times 10^{8} / \mathrm{mL}$; top edge, $1.05 \times 10^{8} / \mathrm{mL}$; bottom edge, $4.23 \times 10^{7} / \mathrm{mL}$; top center, $2.21 \times 10^{7} / \mathrm{mL}$; bottom center, $1.10 \times 10^{7} / \mathrm{mL}$.。

For aerobic and facultative anaerobic ammonifiers, the extremum did not appear in the top position, indicating less dependency on oxygen than acidifying bacteria, which comprised most of the facultative anaerobic bacteria. The spatial change trend of aerobic and facultative anaerobic ammonifying bacteria showed similarities to acidifying bacteria, but its distribution was more uniform inside the reactor, with higher values at the center. At the middle height, edge values were slightly higher than the center. Analysis of the change trends for the different types of bacteria shows that in the early stage of dry anaerobic fermentation, aerobic and facultative anaerobic acidifying bacteria were 
predominant and played a role in the degradation of organic matter and the combination of the necessary precursor substances for methane production. In the next phase, the aerobic and facultative anaerobic ammonifying bacteria proliferated and dominated, effectively preventing $\mathrm{pH}$ decline, and providing the appropriate conditions for the next step of methane bacteria activity.

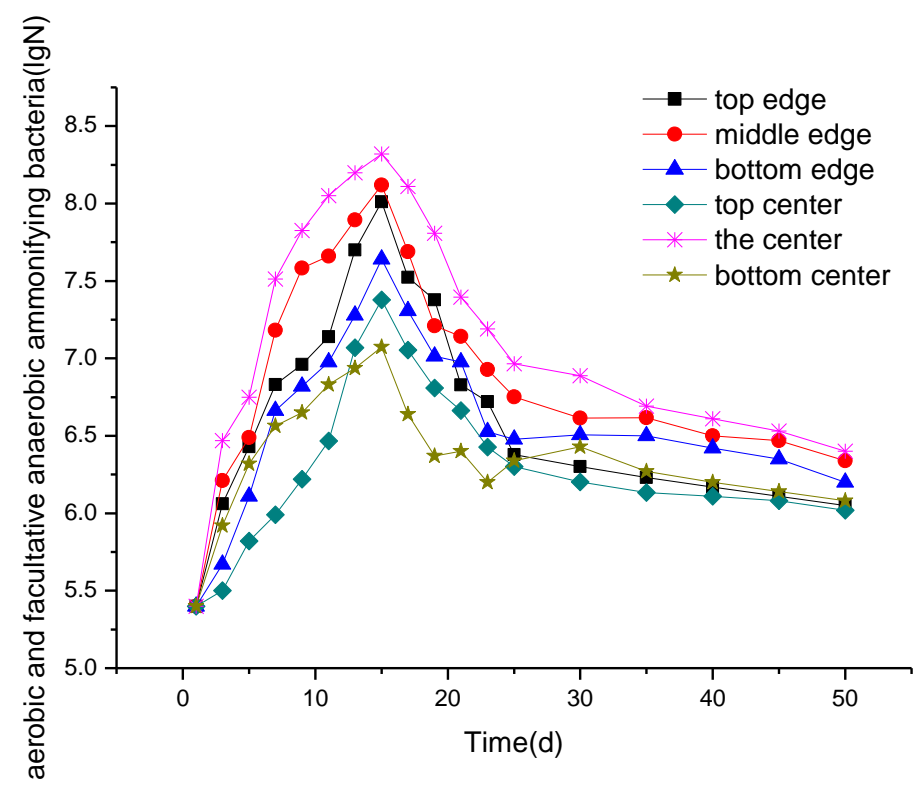

Figure 4. Space and time differences of aerobic and facultative anaerobic ammonifying bacteria

\section{Anaerobic acidifying bacteria}

At the start of the anaerobic fermentation process, the presence of oxygen in the reactor inhibited the growth of anaerobic bacteria (Hansen and $\mathrm{Yu}, 2005$ ). With the formation of the anaerobic environment and the nutrient-rich phase, the number of anaerobic acidifying bacteria started rising rapidly in the 10th day after feeding, as shown in Figure 5. As oxidation-reduction potential decreased, environmental conditions became suitable for the growth of anaerobic bacteria. The maximum number of anaerobic acidifying bacteria was reached around the 15 th day, then the number dropped steadily.

As shown in the spatial distribution of Figure 5, the number of anaerobic acidifying bacteria was largest at the bottom center, with a maximum of $3.82 \times 10^{10} / \mathrm{mL}$. The maximum bacteria numbers at the other positions were as follows: bottom edge, $1.24 \times 10^{10} / \mathrm{mL}$; middle edge, $8.17 \times 10^{9} / \mathrm{mL}$; center, $7.71 \times 10^{9} / \mathrm{mL}$; top center, $3.26 \times 10^{9}$ $/ \mathrm{mL}$; top edge, $1.18 \times 10^{9} / \mathrm{mL}$. An overall trend in the anaerobic acidifying bacteria numbers can be seen: the center positions contained more than the edge positions, and the bottom positions more than the top. Anaerobic acidifying bacteria belong to the bacterial flora that degrade organic matter in the later stages of dry anaerobic fermentation (Rincon et al., 2006). At this point, the number of aerobic and facultative anaerobic acidifying 
bacteria decreased, while anaerobic acidifying bacteria and aerobic and facultative anaerobic ammonifying bacteria reached the maximum. These two groups of bacteria are believed to form a dynamic balance within the space at this time. The number of anaerobic acidifying bacteria was lower at the top of the reactor than at any other position, because the residual air at the top during the initial stage was not conducive to the growth of anaerobic bacteria.

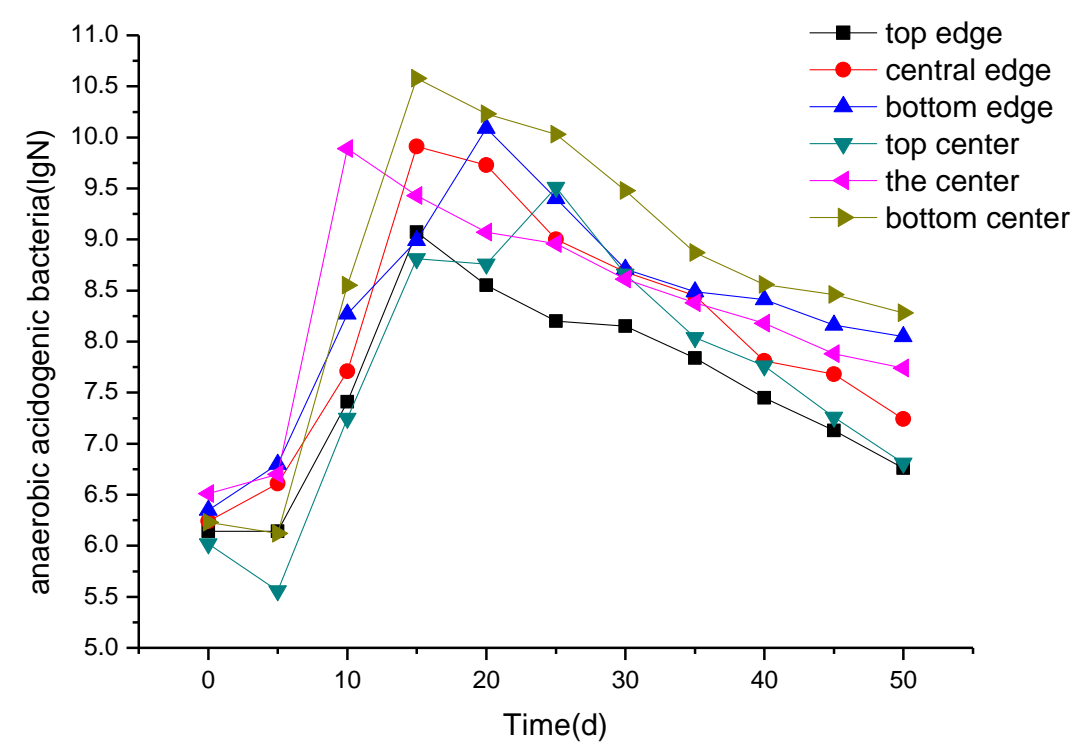

Figure 5. Space and time differences of anaerobic acidifying bacteria

\section{Anaerobic ammonifying bacteria}

Ammonifying bacteria can decompose protein to produce ammonia. The rapid hydrolysis of nitrogen material in the substrate by ammonifying bacteria provides the requisite material for methane bacteria growth, while adjusting the $\mathrm{pH}$ value to create a conducive environment for the growth of a mixed microbial community (Forster-Carneiro et al., 2008; Ahring et al., 2001). As shown in Figure 6, at the beginning of fermentation, the number of bacteria decreased slightly, possibly because the addition of oxygen and environmental $\mathrm{pH}$ change was not suitable for bacterial growth. Subsequently, through a variety of microbial synergies, the anaerobic environment emerged, and anaerobic ammonifying bacteria multiplied. The change trend of the anaerobic ammonifying bacteria was similar to that of anaerobic acidifying bacteria, but the ammonifying bacteria proliferation rate was lower than that of acid-producing bacteria in the initial fermentation period. Among the types of anaerobic bacteria present, acid-producing bacteria reached the maximum earlier than ammonifying bacteria and were dominant. As a result, the $\mathrm{pH}$ within the tank dropped during the initial fermentation period to the lowest point in the whole fermentation process. 
In the spatial distribution, anaerobic ammonifying bacteria were most abundant at the middle edge and the center position, suggesting that proliferation requires relatively stable $\mathrm{pH}$ value and moisture content. Conversely, the residual air present at the top during the initial stage, the water shortage at the top in the later stage, and the accumulation of biogas slurry at the bottom all resulted in fewer ammonifiers at those positions. The maximum number of anaerobic ammonifiers at each test site was reached at around 20 days: middle edge, $1.23 \times 10^{10} / \mathrm{mL}$; center, $9.41 \times 10^{9} / \mathrm{mL}$; bottom edge, $6.57 \times 10^{9} / \mathrm{mL}$; bottom center, $4.05 \times 10^{9} / \mathrm{mL}$; top edge, $2.22 \times 10^{9} / \mathrm{mL}$; top center, $1.17 \times 10^{9} / \mathrm{mL}$.

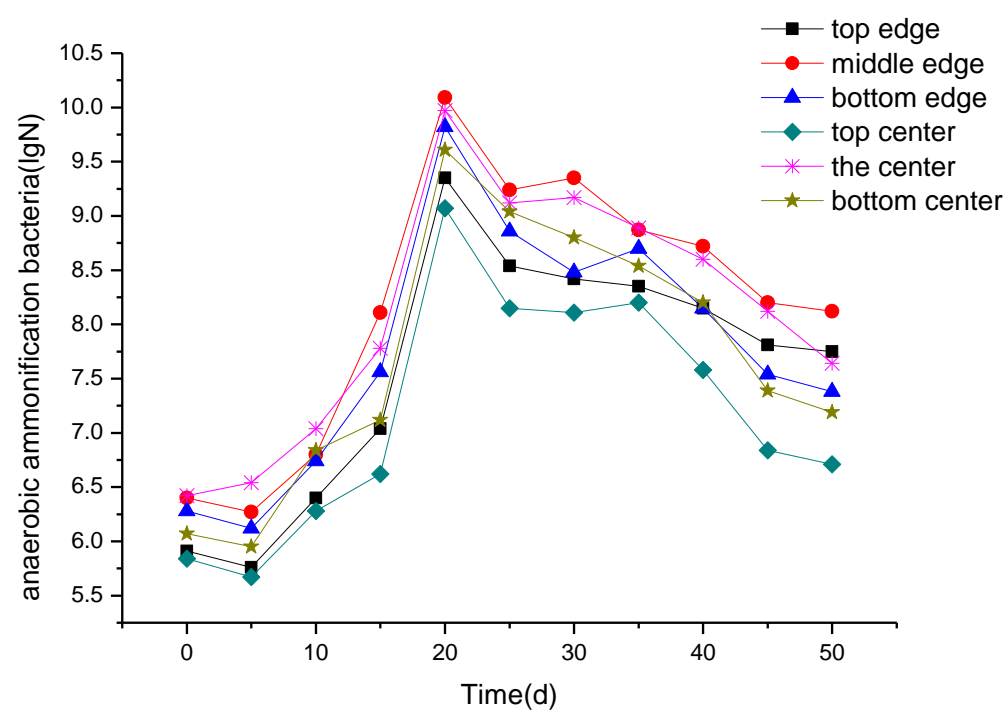

Figure 6. Space and time differences of anaerobic ammonifying bacteria

\section{Anaerobic cellulose-degrading bacteria}

As shown in Figure 7, the number of anaerobic cellulose-degrading bacteria showed a trend of slow growth, rising slowly at the early stages of the fermentation, and increasing to $10^{6} / \mathrm{mL}$ at 45 days. The period of greatest gas production (around 25 days) did not coincide with the maximum number of anaerobic cellulose-degrading bacteria; the material used for the production of biogas was not from the decomposition of cellulose, but from the easily decomposed organic matter. In the continuous gas phase, the number of anaerobic ammonifying bacteria and anaerobic acidifying bacteria began to decline; the cellulose-degrading bacteria were the only microbial colony to continue rising during this period. The main precursor of the methane produced during this period was formed by the decomposition of cellulose (Klockea et al., 2007; Mladenovska et al., 2003).

In the spatial distribution of anaerobic cellulose-degrading bacteria, the most abundant position was the bottom of the fermentation tank. Liquefication of the bottom substrate provided the necessary liquidity, so anaerobic degrading bacteria first proliferated from the bottom edge. The maximum values at each position were as follows: bottom edge, 
$1.16 \times 10^{7} / \mathrm{mL}$; bottom center. $7.21 \times 10^{6} / \mathrm{mL} ;$ middle edge, $3.31 \times 10^{6} / \mathrm{mL}$; center, $1.05 \times 10^{6} / \mathrm{mL}$; top edge, $2.25 \times 10^{5} / \mathrm{mL}$; top center, $1.17 \times 10^{4} / \mathrm{mL}$.

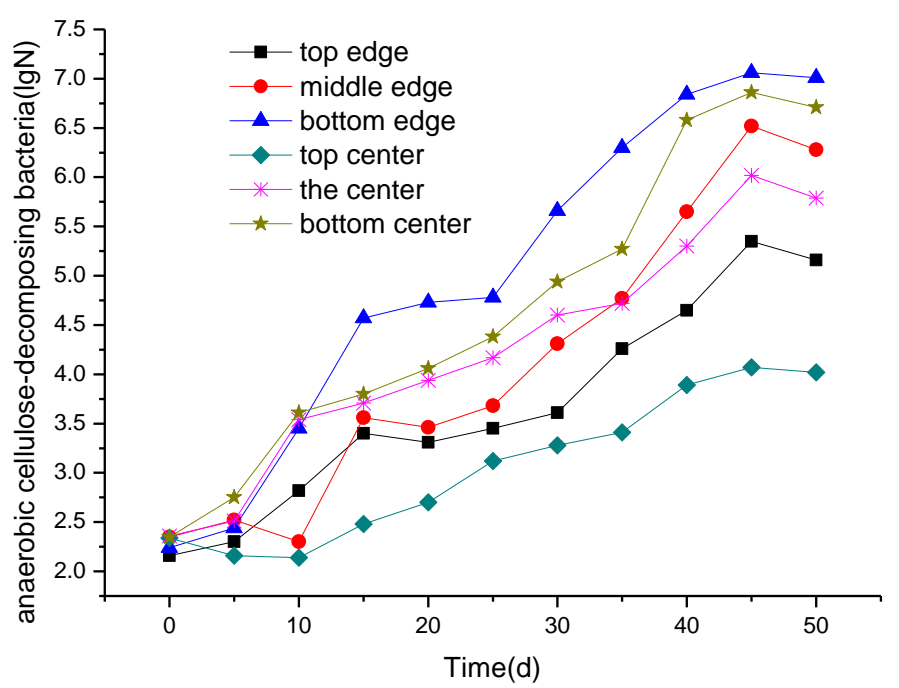

Figure 7. Space and time differences of anaerobic cellulose-decomposing bacteria

\section{Methane bacteria}

As shown in Figure 8, methanogens did not proliferate at the beginning of fermentation, but later in the initial stage (around 15 days), the methanogens grew in number from $10^{5}$ to $10^{6}$. During this period, although gas production rate was very low, $\mathrm{CH}_{4}$ content increased from $8 \%$ to $40 \%$, primarily due to the rapid proliferation of methanogens. The 15-day period of slow methanogen growth was followed by a fast-growth period, and the maximum of $3.36 \times 10^{9} / \mathrm{mL}$ was observed at around 25 days. At this time, the methane content reached more than $60 \%$. The number of methanogens remained at the same order of magnitude throughout the gas-producing period, then declined to $10^{7} / \mathrm{mL}$ until the end of fermentation. After the gas peak, because of the consumption of easily decomposable substrate, anaerobic ammonifying bacteria and anaerobic acidifying bacteria began to decline, while the methane bacteria count remained high. The decline in gas production despite the abundance of menthanogens shows that the decreasing anaerobic acidifying bacteria and anaerobic ammonifying bacteria resulted in a lower gas production rate. Therefore, coordination of the three types of microbial growth is necessary to maintain optimal gas production (Zhang et al., 2006; Schluter et al., 2008).

The spatial distribution of methane bacteria numbers in the fermentation tank show more in the center than at the edges, and more at the bottom than the top. This is due to the matrix condition being the most stable at the center of the reactor, the acidifying bacteria producing the most organic acid in the middle and bottom, and the higher liquidity of the bottom allowing a faster mass transfer process that is suitable for methane bacteria 
growth. The maximum numbers of methane bacteria were, in order, bottom center, $3.36 \times 10^{9} / \mathrm{mL}$; center, $1.64 \times 10^{9} / \mathrm{mL}$; middle edge, $8.75 \times 10^{8} / \mathrm{mL}$ : bottom edge, $4.91 \times 10^{8} / \mathrm{mL}$; top center, $3.79 \times 10^{8} / \mathrm{mL}$; top edge, $1.78 \times 10^{8} / \mathrm{mL}$.

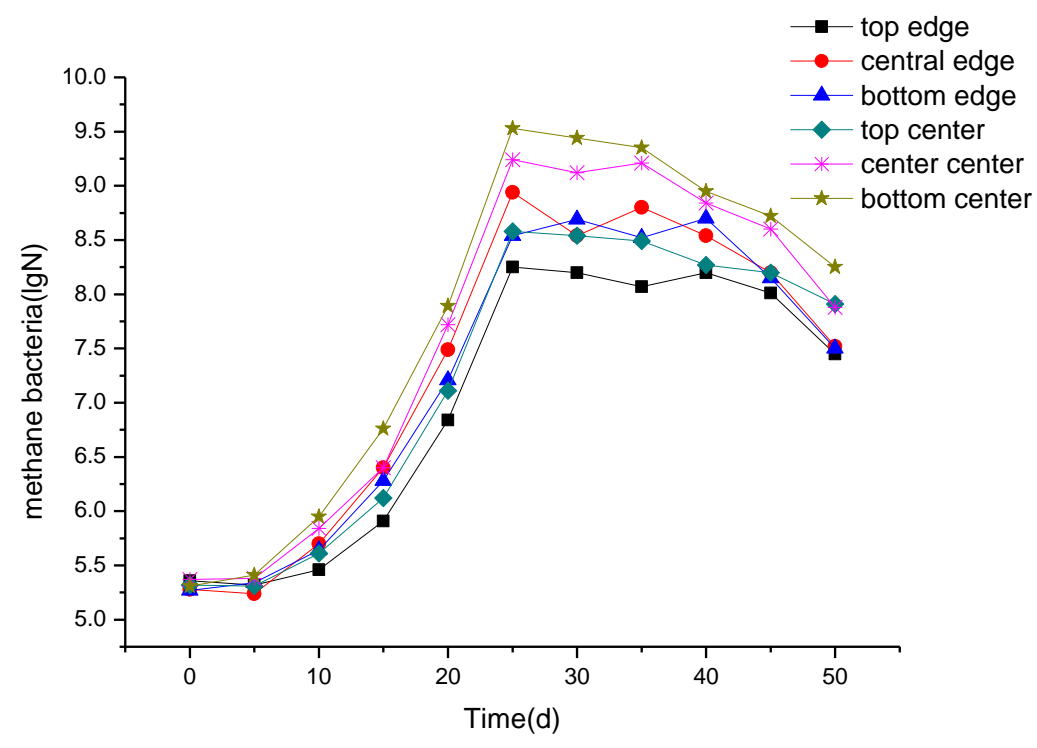

Figure 8. Space and time differences of methane bacteria

\section{The relationship between metabolites}

The function between acidifying bacteria, methane bacteria, and ammonifying bacteria

The acidogenic and methanogenic stages of anaerobic fermentation connect with and complement each other in the production of biogas (Funk et al., 2005). Anaerobic ammonifying bacteria played a regulatory role in the two stages (Hoj et al., 2008). As Figure 9 shows, in the initial fermentation period, volatile fatty acid concentration increased rapidly due to the rapid proliferation of acidifying bacteria. VFA concentration reached the highest value of $8.62 \mathrm{~g} / \mathrm{L}$ on the 15 th day, then began to decline. The biogas production was $10.4 \mathrm{~L} / \mathrm{d}$ at the 15 th day, while the $\mathrm{CH}_{4}$ content of biogas was only $40 \%$. Gas production and methane content both increased rapidly from the 15th day until the 27 th day, when gas production was $24.1 \mathrm{~L} / \mathrm{d}$ and methane content reached a maximum of $75.41 \%$. The results show that most of the acid was produced in the first 15 days after the feeding, which defined the acidogenic phase. The methane bacteria began using these organic acids after 15 days, when the fermentation process transitioned to the methane-producing phase. As the acidogenic phase gradually ended, the balance of acidifying bacteria and methane bacteria allowed fermentation to run proceed.

While acidifying bacteria were most active, ammonifying bacteria also played a crucial role. When the concentration of volatile fatty acid rose rapidly, the ammonia nitrogen concentration also increased sharply. As shown in Figure 10, the presence of ammonia was first observed about 10 days after feeding, and the concentration increased 
threefold to its peak value on the 20th day. As the concentration of ammonia nitrogen began to reach its peak, volatile fatty acid began to decline; this phenomenon suggests the role of ammonifying bacteria in adjusting $\mathrm{pH}$.

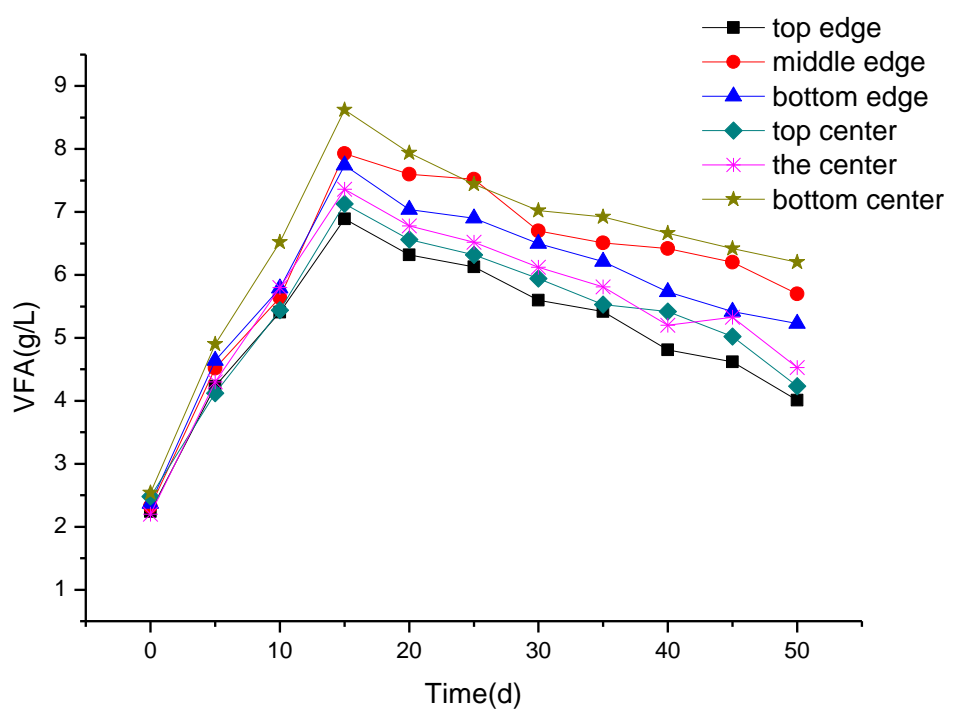

Figure 9. Trend of VFA

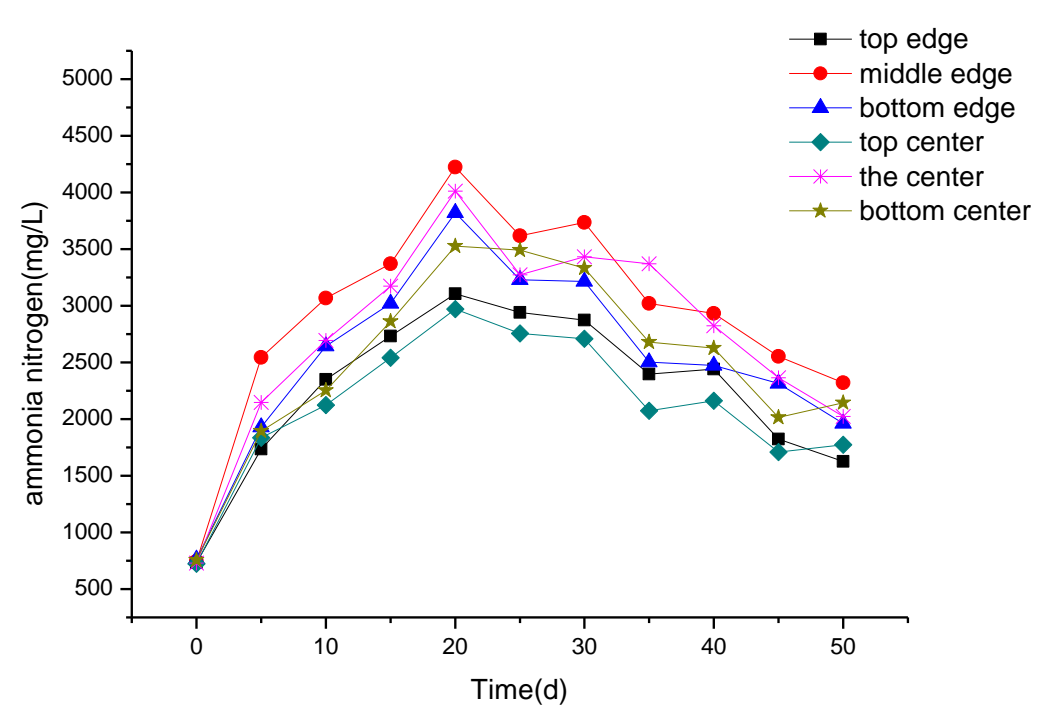

Figure 10. Trend of ammonia nitrogen

Due to the relatively static conditions at the center of the anaerobic dry fermentation reactor, there were differences in the spatial distribution of the various microbes. The highest numbers of acidifying bacteria were found at the middle and bottom positions, as were the most volatile fatty acids, and consequently more methane bacteria. There were 
more ammonifying bacteria at the middle positions, where the ammonia nitrogen concentration was higher.

These results indicate a dynamic balance of liquefying, acid-producing and methanogenic processes in the anaerobic fermentation of municipal solid waste. Initially, fermentation substrate liquefaction fueled acid-producing bacteria, and volatile fatty acid concentration and $\mathrm{pH}$ value rose rapidly. As ammonifying bacteria acted to lower the $\mathrm{pH}$, the oxidation-reduction potential decreased, and the environment became suitable for the growth of methanogens, resulting in a rapid increase in the methane content (Lehtomaki et al., 2007). These three kinds of bacteria depended on each other and restricted each other, enabling fermentation to occur.

\section{The relationship of acidifying bacteria}

Within the mixed microbial community of the conventional reactor, niche complementarity and niche overlap exist between populations. These processes of collaboration and competition enable the formation of different acid products in the reactor (Cohen et al., 1979). The term 'volatile fatty acids' refers to a mixture of organic acids produced by the anaerobic fermentation of municipal solid waste, including acetic acid, propionic acid, butyric acid, valeric acid and caproic acid. The composition of VFA directly affects the efficiency of anaerobic fermentation, so analysis of the organic acids is important. Anaerobic acidification is classified according to the composition of the fermentation product, such as butyric acid fermentation, propionic acid fermentation, alcohol fermentation and mixed acid fermentation. Many researchers believe that propionate is unfavorable for methane production, while acetic acid, formic acid and hydrogen can be used directly by methane bacteria (Dinopoulou et al., 1988; Nane et al., 1996). Therefore, the major ingredients of volatile fatty acids were analyzed.

As shown in Figure 11, acetic acid and butyric acid concentrations were high at the beginning of fermentation, and increased with time until reaching a stable value. Butyric acid had the highest concentration in the fermented liquid; it reached a peak value of 3.86 $\mathrm{g} / \mathrm{L}$ in the fourth day, accounting for $60 \%$ of the total VFA. Acetic acid content reached its highest value of $2.27 \mathrm{~g} / \mathrm{L}$ in the 20th day, accounting for $35.7 \%$ of the total VFA. In the early stages of anaerobic hydrolysis-acidification, propionic acid content was low, and slowly rose with time. Due to the low hydrogen partial pressure, propionic acid produced in the initial fermentation period was easily converted into acetic acid. As the reaction proceeded, hydrogen partial pressure gradually increased, and the propionic acid was converted into acetic acid with more difficulty, leading to gradual accumulation and increased concentration of propionic acid. Valeric acid and caproic acid concentrations were lower throughout anaerobic fermentation, exhibited slow growth, and did not reach a steady state. Most of the valeric acid and caproic acid production occurred in the late fermentation period.

Among the acids created as bacteria break down organic matter, butyric acid is the most important to the anaerobic fermentation of municipal solid waste. Butyric acid was produced most readily in the early fermentation period, and is preferred over propionic 
acid fermentation. Analysis of the change trends showed that the increase in butyric acid content coincided with a decrease in acetic acid content, demonstrating that the acid-producing bacteria responsible for the decomposition of organic matter and the hydrogen-producing acetogenic bacteria responsible for breaking down fatty acids to produce acetic acid both belong to the advantageous flora of acid-producing bacteria. With the consumption of acetic acid by methanogens and the reduction in hydrogen-producing acetogenic bacteria, butyric acid began to accumulate again. As a result, the reduction of acetic acid content can be used as one indicator of the start of the methane-producing phase.

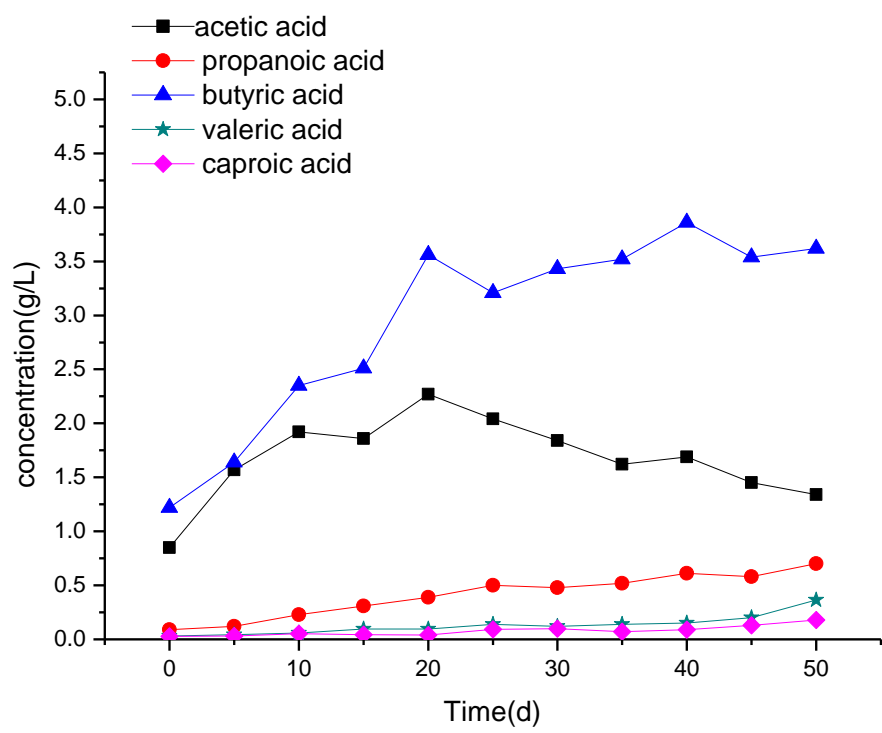

Figure 11. Trend of VFA composition

\section{Conclusion}

(1) During the initial stage of dry anaerobic fermentation, aerobic and facultative anaerobic bacteria proliferated, showing that this group is primarily responsible for transforming raw material into organic matter. Many precursors of methane come from this taxon, so research on the effect of aerobic and facultative anaerobic microbial flora in the early stage of dry fermentation can provide the theoretical basis for further improving the efficiency of biogas production. As anaerobic fermentation continued, the number of aerobes and facultative anaerobes decreased, while anaerobic bacteria reproduced at an increasing rate and became the dominant bacterium group. Anaerobic acidifying bacteria degraded organic matter to provide the precursors for methane synthesis. Among both aerobic and anaerobic bacteria, acidifiers dominated ammonifiers: acidifying bacteria multiplied at a higher rate, reached the maximum population size earlier, and maintained higher numbers than ammonifying bacteria. The number of anaerobic cellulose-degrading bacteria showed a trend of slow growth, increasing to $10^{6} / \mathrm{mL}$ by 45 days after feeding. Methanogens essentially showed no sign of proliferation during the 
initial stage, then entered a period of fast growth, reaching a maximum of $3.36 \times 10^{9} / \mathrm{mL}$ at around 25 days. After the gas peak, ammonifying bacteria and anaerobic acidifying bacteria began to decline in number; the methane bacteria, however, maintained the same order of magnitude.

(2) Due to the relatively static condition of anaerobic dry fermentation inside the reactor, there were differences in the spatial distribution of the microbes. The aerobic and facultative anaerobic acidifying bacteria were more active at the top position, but the changing was not obvious in the same height. The matrix condition was stable at the middle position. The highest numbers of anaerobic ammonifying bacteria were seen at the middle edge and the center positions. Greater liquidity at the bottom position resulted in a higher number of acidifying bacteria to decompose organic acid, enabling the growth of methane bacteria. The anaerobic cellulose-degrading bacteria flourished in the more liquid environment at the bottom. At the top, the number of anaerobic bacteria was lower than in any other place, due to the initial presence of residual air that was not conducive to their growth. Future reactor designs could incorporate an intermediate feed, or supplemental feeding at the edge in order to make full use of the fermentation materials and improve the efficiency of the reactor.

(3) The function between acidifying bacteria, methane bacteria, and ammonifying bacteria was analyzed. During the early period of fermentation substrate liquefaction, acidifying bacteria used liquefied carbohydrates and fat to create large amounts of acid, raising the volatile fatty acid concentration. As the ammonifying bacteria produced more ammonia, the volatile fatty acid concentration decreased, and the oxidation-reduction potential was reduced. This environment, suitable for methanogen growth, allowed the methane content to rise rapidly. The change trend of volatile fatty acids and concentration of ammonia nitrogen was consistent with the spatial distribution of bacteria; where there were more bacteria, there were more products.

(4) The relationship between different types of acidifying bacteria. The most prevalent acid in the VFA composition of biogas slurry, and thus the main product of acidifying bacteria in the anaerobic fermentation of municipal solid waste, was butyric acid. Butyric acid fermentation was conducive to the methanogenic process. Acetic acid, the product of hydrogen-producing acetogenic bacteria, was the substrate directly utilized by methanogens in the next stage; its presence can be used as one of the indicators of the start of the methane-producing phase. In the early stages of anaerobic hydrolysis acidification, propionic acid content was low, and slowly increased with time. Valeric acid and caproic acid content remained low throughout the whole process of anaerobic fermentation; for these two acids, growth remained slow and did not reach a steady state.

Acknowledgements. This work was supported by the Cultivation Plan for Youth Agricultural Science and Technology Innovative Talents of Liaoning Province (2014016). 


\section{REFERENCES}

[1] Ahring, B. K., Ibrahim, A. A., Mladenovska, Z. (2001): Effect of temperature increase from 55 to $65^{\circ} \mathrm{C}$ on performance and microbial population dynamics of an anaerobic reactor treating cattle manure. - Water Research 35: 2446-2452.

[2] APHA. (1995): Standard method for the examination of water and wastewater. American Public Health Association. 111-128.

[3] Cheng, H., Hu, Y. (2010): Municipal solid waste (MSW) as a renewable source of energy: current and future practices in China. - Bioresour. Technol. 101: 3816-3824.

[4] China, N.B.o.S.o. (2012): 2012 China Statistical Yearbook. - China Statistics Press, Beijing.

[5] Cohen, A., Zoetemeyer, R. J., Deursen, A., et al. (1979): Anaerobic digestion of glucose with separated acid production and methane formation. - Water Research 13: 571-580.

[6] De Baere, L., Mattheeuws, B. (2010): Anaerobic digestion of MSW in Europe. - Biocycle 51: 24-26.

[7] Dinopoulou, G., Rudd, T., Lester, J. N. (1988): Anaerobic acidogenesis of a complex wastewater. - Biotech Bioeng 31: 958-968.

[8] Eikmeyer, F. G., Rademacher, A., Hanreich, A., Hennig, M., Jaenicke, S., Maus, I., Wibberg, D., Zakrzewski, M., Pühler, A., Klocke, M., Schlüter, A. (2013): Detailed analysis of metagenome datasets obtained from biogas-producing microbial communities residing in biogas reactors does not indicate the presence of putative pathogenic microorganisms. - Biotechnol Biofuels 6: 49-52.

[9] El-Mashad, H. M., McGarvey, J. A., Zhang, R. (2008): Performance and microbial analysis of anaerobic digesters treating food waste and dairy manure. -Biol. Eng. 1: 233-242.

[10] Fernández, J., Pérez, M., Romero, L. I. (2008): Effect of substrate concentration on dry mesophilic anaerobic digestion of organic fraction of municipal solid waste (OFMSW). Bioresour. Technol 99: 6075-6080.

[11] Forster-Carneiro, T., Perez, M., Romero, L. I. (2008): Thermophilic anaerobic digestion of source-sorted organic fraction of municipal solid waste. - Bioresource Technology 99: 6763-6770.

[12] Funk, P. A., Armijo, C. B., Hanson, A. T., Samani, Z. A., Macias-Corral, M. A., Smith, G. B., Riordan, J. T. (2005): Converting gin and dairy wastes to methane. - Transactions of the ASAE 48: 1197-1201.

[13] Ghosh, S., Henry, M. P., Sajjad, A., et al. (2000): Pilot-scale gasification of municipal solid wastes by high-rate and two-phase anaerobic digestion (TPAD). -Water Sci. Technol 41: 101-110.

[14] Gonzáleza, C.R.-N., Björklund, E., Forteza, R., Cerdàa, V. (2013): Volatile organic compounds in landfill odorant emissions on the island of Mallorca. Int. J. Environ. - Anal. Chem 93: 434-449.

[15] Hansen, Z. H., Yu, H. Q. (2005): Application of rumen microorganism for enhanced anaerobic fermentation of corn stover. -Process Biochemistry 40: 2371-2377.

[16] Hartmann, H., Ahring, B. K. (2006): Strategies for the anaerobic digestion of the organic fraction of municipal solid waste: an overview. -Water Sci. Technol. 53:7-22.

[17] Hoj, L., Olsen, R. A., Torsvik, V. L. (2008): Effects of temperature on the diversity and community structure of known methanogenic groups and other archaea in high Arctic peat. -ISME Joumal 2: 37-48.

[18] Igoni, A. H. (2006): Design of anaerobic bio-reactors for the simulation of biogas production from municipal solid-waste. - Ph.D. Thesis of the Rivers State University of Science and Technology, Port Harcourt, Nigeria: 261.

[19] Igoni, A. H., Eze, C. L., Ayotamuno, M. J., Abowei, M. F. N. (2005): Potentials of biogas 
generation from municipal solid-waste in the Port Harcourt Metropolis. - Proceedings of the 1st annual conference of Science and Technology Forum 1(2): 67-72.

[20] Klockea, M., Mahnert, P., Mundt, K., Souidi, K., Linke, B. (2007): Microbial community analysis of a biogas-producing completely stirred tank reactor fed continuously with fodder beet silage as mono-substrate. - Systematic and Applied Microbiology 30: $139-151$.

[21] Kovács, E., Wirth, R., Maróti, G., Bagi, Z., Rákhely, G., Kovács, K. L. (2013): Biogas production from protein-rich biomass: fed-batch anaerobic fermentation of casein and of pig blood and associated changes in microbial community composition. - PLoS ONE 8(10): 257-265.

[22] Lehtomaki, A., Huttunen, S., Rintala, J. A. (2007): Laboratory investigations on co-digestion of energy crops and crop residues with cow manure for methane production: Effect of crop to manure ratio. - Resources Conservation \& Recycling 51(3): 591-609.

[23] Li, R., Chen, S., Li, X. (2010): Biogas production from anaerobic co-digestion of food waste with dairy manure in a two-phase digestion system. Appl. - Biochem. Biotechnol. 160: 643-654.

[24] Macias-Corral, M., Samani, Z., Hanson, A., Smith, G. (2008): Anaerobic digestion of municipal solid waste and agricultural waste and the effect of co-digestion with dairy cow manure. - Bioresource Technology 99: 8288-8293.

[25] Mladenovska, Z., Dabrowski, S., Ahring, B. K. (2003): Anaerobic digestion of manure and mixture of manure with lipids: biogas reactor performance and microbial community analysis. - Water Science \& Technology 48: 271-278.

[26] Motte, J. C., Trably, E., Escudié, R., Hamelin, J., Steyer, J. P., Bernet, N., Delgenes, J. P., Dumas, C. (2013): Total solids content: a key parameter of metabolic pathways in dry anaerobic digestion. -Biotechnol Biofuels 6: 164-170.

[27] Nane, B., Matsui, S., Ied, S. (1996): Propionic acid accumulation and controlling factors in anaerobic treatment of carbohydrate: Effects of $\mathrm{H}_{2}$ and $\mathrm{pH}$. - Water Science and Technology 34: 317-325.

[28] Nopharatana, A., Pullammanappalli, P. C., Clarke, W. P. (2007): Kinetics and dynamic modelling of batch anaerobic digestion of municipal solid waste in a stirred reactor. Waste Manage 27: 595-603.

[29] Renou, S., Givaudan, J. G., Poulain, S., Dirassouyan, F., Moulin, P. (2008) : Landfill leachate treatment: review and opportunity. - J. Hazard. Mater. 150: 468-493.

[30] Rincon, B., Raposo, F., Borja, R. (2006): Performance and microbial communities of a continuous stirred tank anaerobic reactor treating two-phases olive mill solid wastes at low organic loading rates. - Biotechnol. 121: 534-543.

[31] Schluter, A., Bekel, T., Naryttza, N. (2008): The metagenome of a biogas-producing microbial community of a production-scale biogas plant fermenter analysed by the 454-pyrosequencing technology. - Journal of Biotechnology 136: 77-90.

[32] Shi, D.Z., Wu,W.X., Lu, S.Y., Chen, T., Huang, H.L., Chen, Y.X., Yan, J.H. (2008): Effect of MSW source-classified collection on the emission of PCDDs/Fs and heavy metals from incineration in China. - Hazard. Mater. 153: 685-694.

[33] Tyagi, V. K., Angériz Campoy, R., Álvarez-Gallego, C. J., Romero García, L. I. (2014): Enhancement in hydrogen production by thermophilic anaerobic co-digestion of organic fraction of municipal solid waste and sewage sludge -optimization of treatment conditions. -Bioresour Technol 164: 408-415.

[34] Wan, S., Sun, L., Douie, Y., Sun, J., Luo, W. (2013): Anaerobic digestion of municipal solid waste composed of food waste, wastepaper, and plastic in a single-stage system: Performance and microbial community structure characterization. - Bioresource Technology 146: 619-627. 
[35] Yin, D., Liu, W., Zhai, N., Yang, G., Wang, X., Feng, Y., Ren, G. (2014): Anaerobic digestion of pig and dairy manure under photo-dark fermentation condition. - Bioresour. Technol. 166: 373-380.

[36] Zhang, Z. P., Show, K. Y., Tay, J. H. (2006): Effect of hydraulic retention time on biohydrogen production and anaerobic microbial community. - Process Biochemistry 41: $2118-2123$. 